\title{
ФОРМУВАННЯ ГЕОЕКОЛОГІЧНОЇ КОМПЕТЕНТНОСТІ МАЙБУТНІХ ФАХІВЦІВ 3 ТУРИСТИЧНОГО ОБСЛУГОВУВАННЯ У КОНТЕКСТІ СТАЛОГО РОЗВИТКУ
}

\author{
Мар'ян Сеньків, \\ аспірант Інституту професійно-технічної освіти НАПН Украӥни
}

\section{КЛЮЧОВІ СЛОВА: \\ освіта сталого розвитку, професійна освіта, компетентнісний підхід, геоекологічна компетентність}

\begin{abstract}
Реферат
У статті проаналізовано дослідження вітчизняних та зарубіжних науковців із проблеми забезпечення якості професійної освіти в умовах сталого розвитку українського суспільства, нормативно-правові документи стосовно модернізації професійної освіти в Україні. Акцентовано увагу на необхідності постійного оновлення змісту професійного навчання з урахуванням потреб суспільства й вимог національного ринку праці. Підкреслено важливість формування соціальних і творчих рис особистості фахівця, його професійно важливих якостей. Розглянуто умови формування геоекологічної компетентності майбутніх фахівців із туристичного обслуговування в контексті сталого розвитку; наведено визначення понять: «компетентність», «сталий розвиток», «геоекологічна культура»; обгрунтовано суть компетентнісного підходу до формування системи знань, умінь і навичок майбутніх фахівців 3 туристичного обслуговування, що відповідає вимогам сфери туризму; сформульовано авторське поняття «геоекологічна компетентність майбутніх фахівців 3 туристичного обслуговування»; розкрито компоненти геоекологічної компетентності (ціннісно-мотиваційний, інноваційно-когнітивний, суб'єктно-діяльнісний, рефлексивно-оцінний).

Опрацьовано «Національну стратегію розвитку освіти в Україні на період до 2021 року», яка серед перспективних завдань визначає оновлення цілей і змісту освіти на основі компетентного підходу й особистісної орієнтації, врахування світового досвіду та принципів сталого розвитку. Охарактеризовано процес формування геоекологічної компетентності фахівців 3 туристичного обслуговування (на прикладі дисципліни «Екологія») та виокремлено найголовніші завдання, згідно 3 якими відбувається становлення особистості в соціальному та професійному середовищах. Увагу приділено основним положенням державної освітньої політики 3 удосконалення системи професійної освіти і навчання в контексті сталого розвитку суспільства. Доведено, що реалізація означених завдань буде неможливою без набуття фахівцями ключових компетентностей (інструментальних, міжособистісних і системних), тобто професійної компетентності, у структурі якої особливе місце відведено геоекологічній компетентності
\end{abstract}

\begin{abstract}
Постановка проблеми. Формування освіти сталого розвитку (далі - ОСР) $є$ базовою умовою трансформації світового суспільства, а для нашої країни - першим кроком на шляху включення іï в процес формування стратегії сталого розвитку. Основні цілі освіти сталого розвитку сформульовано в низці міжнародних документів і програм, розроблених під егідою ООН. Освіта сталого розвитку відображає сенс первинного поняття «сталий розвиток» (англ. sustainable development) і визначається як «модель соціально-економічного розвитку держави, що на основі узгодження й гармонізації соціальної, економічної та екологічної складових задовольняє потреби сучасності, не ставлячи під загрозу здатність наступних поколінь задовольняти свої власні потреби» [13; 14]. Варто також розуміти, що сталий розвиток означає процес, а не мету чи зразок функціонування суспільства. Головним чинником сталого розвитку $\epsilon$ адекватне врахування довгострокових тенденцій розвитку системи «природа-суспільстволюдина».
\end{abstract}

У шостому розділі Програми Дій «Порядку денного на XXI століття» було проголошено, що освіта $\epsilon$ фундаментом сталого розвитку, а формування нового світогляду має бути орієнтоване на створення умов для збереження життя на планеті Земля шляхом: переорієнтації освіти на питання сталого розвитку; забезпечення професійної підготовки людей упродовж усього життя; поширення обізнаності населення щодо стану довкілля і проблем виживання людства [9, с. 194]. Для реалізації цих завдань у 2005 р. було прийнято Стратегію освіти для сталого розвитку Європейської Економічної Комісії (СЕК) ООН, яка визначила конкретне завдання для урядів i держав, принципи, організаційні основи реалізації, зокрема включення ОСР в системи формальної й неформальної освіти і навчання [3, с. 50].

Тому, на нашу думку, розроблення й реалізація освітніх програм, навчальнометодичне забезпечення у контексті Концепції сталого розвитку є найважливішим завданням сучасної освітньої галузі. Особливу роль у виконанні цього завдання мають відігравати заклади професійної освіти, 
оскільки саме в їх освітньому середовищі реалізовуються сучасні підходи до формування геоекологічної компетентності майбутніх фахівців 3 туристичного обслуговування.

Аналіз останніх досліджень. Наразі науковцями активно досліджується питання якості професійної підготовки майбутніх фахівців на засадах компетентнісного підходу як найбільш ефективного для освітнього процесу, такого, що відповідає сучасним вимогам суспільства. А саме, з: філософії сучасної освіти (В. Андрущенко, О. Ануфрієва, І. Зязюн, В. Кремень, В. Лутай, В. Огнев'юк та ін.), безперервної професійної освіти (С. Батишев, Л. Герганов, П. Лузан, Н. Ничкало, В. Орлов, Л. Пуховська, В. Радкевич, С. Сисоєва та ін.), фундаменталізації, інтеграції й гуманізації професійної освіти (С. Гончаренко, Р. Гуревич， Ю. Кушнер, О. Новіков та ін.), формування екологічної компетентності (С. Головіна, К. Корсак, О. Колонькова, В. Подоляк, Н. Пустовіт, Дж. Равена А. Хуторський, Л. Хоружа, С. Шмалей та ін.); екологічної культури молоді (Н. Сфименко, Л. Лук'янова, Н. Олійник, О. Пруцакова, Л. Титаренко та ін.); процесу екологічного виховання в учнівському та студентському середовищі (В. Білик, Т. Вайда, В. Крисаченко, Г. Пустовіт, С. Шмалей та ін.); особливості організації екологічної освіти в зарубіжних країнах (В. Ломакович, Г. Марченко, В. Червонецький, М. Швед та ін.); формування геоекологічної компетентності (Н. Демидова, Т. Нечаєва, Л. Розанов).

Результати аналізу наукової та навчальної літератури, нормативних документів, а також результатів дисертаційних досліджень дають змогу дійти висновку, що, попри великий спектр досліджень, проблема формування геоекологічної компетентності майбутніх фахівців 3 туристичного обслуговування в закладах професійної освіти залишається недостатньо розробленою.

Мета статті - розглянути сучасні підходи до формування геоекологічної компетентності майбутніх фахівців 3 туристичного обслуговування в контексті сталого розвитку.

Виклад основного матеріалу. Перехід до нової моделі розвитку освіти на засадах сталості $\epsilon$ важливим засобом управління розвитком економічної, соціальної й екологічної політики, що базується на компетентнісному підході. Його роль $\epsilon$ безперечною, оскільки формування різних компетентностей, зокрема геоекологічної, сприяє розвитку у фахівців активної соціальної позиції, готовності постійно навчатися, здатності адаптуватися до умов суспільного життя, приймати рішення та бути відповідальними за їх наслідки.

Для економіки України XXI століття ідеальним вважається фахівець, особистість якого характеризується почуттям власної гідності, громадянськістю, толерантністю, орієнтацією на соціальне й професійне самовизначення та самореалізацію та поліпрофесіоналізмом, готовністю до здійснення суміжних видів діяльності, удосконалення та оволодіння новими ключовими $\mathrm{i}$ професійними компетентностями $[11$, с. $8 ; 6$, с. $90 ; 8$, с. 66 ; 10 , с. $6 ; 14]$. У контексті сталого розвитку компетентнісний підхід розглядається як новий підхід до цілепокладання у підготовці фахівців, а компетентність утверджується як нова цільова категорія, що слугує спільною мовою для представлення результатів освіти, їх проектування та опису.

Визначальним кроком на шляху розвитку освіти в інтересах сталого розвитку стало прийняття «Національної стратегії розвитку освіти в Україні на період до 2021 року» [1], яка визначає екологізацію освіти, а серед перспективних іiі завдань - оновлення цілей і змісту освіти на основі компетентного підходу та особистісної орієнтації, врахування світового досвіду та принципів сталого розвитку. У Стратегії ЄЕК ООН у галузі освіти в інтересах сталого розвитку загальна мета ОСР націлена на набуття знань i навичок, що сприяють формуванню екологічно свідомого суспільства, нових світоглядних позицій, цінностей, а також розвитку, що $\epsilon$ соціально бажаним, економічно життєздатним i екологічно збалансованим [5].

Найважливішою особливістю сталого розвитку в закладах професійної освіти $€$ практичне освоєння прийомів професійної майстерності 3 широким використанням новітніх технічних засобів, сучасних освітніх та інформаційних технологій. Аналіз педагогічної літератури щодо суті геоекологічної компетентності розкриває 
досить вузьке поле трактувань цього терміну. T. Нечаєва розглядає геоекологічну компетентність як «здатність і готовність застосовувати геоекологічні знання і вміння в професійній діяльності; формувати туристичний продукт, 3 огляду на геоекологічний аспект розвитку туристичної дестинації; проектувати екологічні маршрути; вміння самостійно й оперативно приймати відповідальні рішення» [7, с. 10]. Н. Демидова розглядає поняття «геоекологічна культура» як спосіб, процес, міру і результат культурноісторичного освоєння людиною довкілля 3 метою адаптації, осмислення природоохоронної діяльності, окультурення антропогенно-змінених територій різного просторового рангу на благо гармонії людини з природою. Результатом прояву геоекологічної культури $\epsilon$ геоекологічна компетентність i духовно-моральні якості особистості, що сприяють розвитку шкільної географії в контексті ключових завдань освіти для сталого розвитку [4, с. 19]. Л. Розанова геоекологічну компетентність характеризує як усвідомлення просторово-часової єдності і взаємозв'язку в географічній дійсності природних, соціально-економічних, техногенно-природних i техногенних процесів, об'єктів; правильне використання знань та навичок в суб'єктно-об'єктній діяльності; вміння самостійно розрізняти й оцінювати рівень безпеки чи небезпеки довкілля для вироблення професійної діяльності [12, с. 231].

Відтак, геоекологічна компетентність майбутніх фахівців 3 туристичного обслуговування $\epsilon$ складною інтегративною властивістю особистості, що поєднує науково-природничі знання, вміння, професійно важливі якості ,які визначають іiі активну позицію в галузі охорони навколишнього природного середовища, раціонального використання i відтворення природних ресурсів, забезпечують здатність здійснювати професійну діяльність у галузі туризму 3 позицій геоекологічної обгрунтованості й доцільності.

Відповідно до специфіки поняття «геоекологічна компетентність», визначено його компоненти: ціннісно-мотиваційний ціннісні орієнтири майбутнього фахівця, які впливають на його професійну діяльність: мотиви, необхідності й бажання, прагнення та пізнавальні інтереси людини; інноваційнокогнітивний - сукупність знань, умінь та навичок, необхідних для здійснення майбутньої професійної кар'єри; суб'єктнодіяльнісний - уміння виконувати певні набуті способи та прийоми професійної діяльності для розв'язання відповідних завдань; формування соціокультурної свідомості та соціокультурної відповідальності, культурної толерантності та адекватної поведінки в соціумі 3 іншою культурою; рефлексивнооцінний - формує механізми моніторингу процесу формування геоекологічної компетентності, самоконтролю рівня розвитку власних властивостей, якостей і здібностей, самооцінки фахівцями професійної поведінки, iii осмислення, саморегуляції, прогнозування подальших дій, здатність формулювати оцінні судження, прагнення до самовдосконалення геоекологічної компетентності.

Формування геокологічної компетентності майбутніх фахівців 3 туристичного обслуговуваннями є одним 3 найголовніших завдань сталого розвитку, основними 3 яких є: виховання і практична підготовка вільного, функціонально грамотного фахівця у сфері туристської професійної діяльності, здібного до творчої i продуктивної співпраці; виховання інтересу i прагнення до оволодіння висотами професійної майстерності в тому чи іншому напрямі туристської діяльності: екологічний, науковий, краєзнавчий, спортивний туризм (піший, водний, лижний, велосипедний, автомобільний, морські круїзи, авіатури тощо), у розвитку вітчизняної індустрії туризму i безперервній самоосвіті; вдосконалення навчально-виховного процесу професійної підготовки висококваліфікованих фахівців для різних сфер індустрії туризму на основі використання сучасних освітніх та інформаційних технологій; формування ініціативності та активності студентів завдяки розвитку різноманітних організацій на основі партнерських відносин і продуктивної творчої діяльності.

У кінцевому результаті формується компетентність майбутнього фахівця 3 туризму як якість його особистості, яка дає йому змогу розуміти довкілля не тільки абстрактно, але й візуально, усвідомити його 
комплексність, взаємозалежність, структурнофункціональну суть, уміти керувати ним, не порушуючи екологічної рівноваги. Потреба формування геоекологічної компетентності актуалізується у кількох змістовно самостійних напрямах - гармонізації взаємодії людини і природи, екологічної освіти і компетентністно-орієнтованої освіти. Оскільки збалансованість є результатом узгодження економічно-соціального розвитку суспільства та збереження довкілля, то однією 3 важливих тенденцій в геоекологічній складовій сталого розвитку є формування в студента здатності самостійно вирішувати й діяти в інтересах сталості та збереження довкілля [2]. Основним завданням сучасного науково-педагогічного пошуку $є$ створення системи формування геоекологічної компетентності як невід'ємного складника у структурі професійної компетентності фахівців з туристичного обслуговування.

Розглядаючи питання формування геоекологічної компетентності фахівців 3 туристичного обслуговування в умовах професійної освіти, можна констатувати, що безпосередньо поняття «геоекологічна компетентність» немає, але в освітньопрофесійних програмах підготовки молодших спеціалістів сфери туризму надається 54 академічні години на вивчення дисциплін «Екологія» («Основи екології»), де передбачається формування у студентів знань, умінь і навичок, значущих 3 цього погляду. А певна частина матеріалу виділяється на самостійне опрацювання студентами. Зокрема, серед завдань курсу зазначено: розвиток умінь встановлювати гармонійні стосунки 3 природою на основі поваги до життя як найвищої цінності та всього живого як унікальної частини біосфери; формування емоційно-ціннісного ставлення до природи, до себе, а також оволодіння таким важливим умінням, як технологія прийняття рішень, вільного вибору і дій у різних сферах життя, що розглядається як складник компетентності. Аналіз навчальних програм дає підстави для висновку про переважно загальнонауковий характер екологічних знань. Вони стосуються глобальних i регіональних екологічних проблем та зв'язків. А ситуацію, яка склалася 3 викладанням геоекологічних знань у майбутніх фахівців сфери туризму, можна вважати як незадовільну. Адже включення окремих геоекологічних питань до навчальних програм не вирішує проблем формування системи геоекологічних знань та екологічного світогляду у фахівця, оскільки геоекологічна компетентність має відмінні від екології як науки об'єкти вивчення, мету, завдання, принципи i методологію. Отже, результати аналізу сучасного стану професійної підготовки майбутніх фахівців з туристичного обслуговування свідчать про недостатність забезпечення необхідних сучасних підходів для формування в них геоекологічної компетентності.

Результати аналізу навчальних планів i державних стандартів підготовки фахівців 3 туристичного обслуговування дають змогу стверджувати, що вони повинні володіти соціальними,

гуманітарними, культурологічними, історичними, правовими, естетичними, рекреаційними, екологічними, економічними та іншими аспектами знань, двома-трьома іноземними мовами, сучасними комп'ютерними інформаційними технологіями. 3 іншого боку, професіоналам туристичної індустрії мають бути притаманні доброзичливість, знання психології, уміння самостійного надання різних видів туристських послуг, що зумовлює необхідність наявності фундаментальних знань

Висновок. Модернізація професійної освіти спрямована на реалізацію цілей та завдань сталого розвитку, розроблених під егідою ООН, що стосуються широкого спектру питань, зокрема - освітніх. В Україні принципи сталого розвитку чітко відображені в «Національній стратегії розвитку освіти в Україні на період до 2021 року», яка визначає перспективні завдання оновлення цілей i змісту освіти на основі сучасних підходів. Основними завданнями сучасної професійної освіти майбутніх фахівців 3 туристичного обслуговування можна вважати: підготовку конкурентоспроможних, компетентних, високопрофесійних фахівців, здатних відповідально ставитися до проблем довкілля, застосовувати геоекологічні знання і досвід у професійних та життєвих ситуаціях, а також новітні й технічні засоби, інформаційнокомунікаційні технології тощо. Є очевидним те, що реалізація означених завдань буде можливою за умови набуття студентами ключових

(інструментальних, компетентностей міжособистісних i 
Мар’ян Сеньків. Формування геоекологічної компетентності майбутніх фахівців з туристичного обслуговування у контексті сталого розвитку

системних), а також професійної місця матиме геоекологічна компетентність. компетентності, у структурі якої особливе

\title{
Література
}

1. Указ Президента України від 25.06.2013 р. № $344 / 2013$ «Про Національну стратегію розвитку освіти в Україні на період до 2021 року» - [Електронний ресурс]: - Режим доступу: http://zakon5.rada.gov.ua/laws/show/344/2013

2. Ануфрієва О. Л. Компетентнісний підхід до економічної освіти / О. Л. Ануфрієва. - [Електронний pecypc]. - Режим доступу : www.cippe.edu.ua.

3. Бондар О. І. Екологічна освіта для сталого розвитку у запитаннях та відповідях : науковометодичний посібник для вчителів / Бондар О. I., Барановська В. Є., Єресько О. В. та ін..; за ред. О. І. Бондаря. - Херсон : Грінь Д. С., 2015. - 228 с.

4. Демидова Н. Н. Теория и методика формирования геоэкологической культуры школьников средствами географи: диссертация доктора педагогических наук: 13.00.02 /Демидова Наталья Николаевна; [ФГБОУ ВПО «Нижегородский государственный педагогический университет»]. Нижний Новгород, 2012. - 346 с.

5. Свропейська економічна комісія (СЕК) ООН «Освіта в інтересах сталого розвитку в Україні» від 2005p. - [Електронний ресурс]. - Режим доступу: http://dea.gov.ua/chapter/koncepciya_regional4noi_sistemi_ osviti_dlya_stalogo_rozvitku

6. Компетентнісний підхід у сучасній освіті: світовий досвід та українські перспективи: Бібліотека 3 освітньої політики: колективна монографія / [Н.М. Бібік, Л.С. Ващенко, О.І. Локшина [та ін.]; за заг. ред. О.В.Овчарук. - К. : «К.І.С.», 2004. - 112 с.

7. Нечаева Т. А. Формирование геоэкологической компетентности при подготовке специалистов по туризму в образовательных учреждениях среднего профессионального образования: диссертация кандидата педагогических наук: 13.00.08 / Нечаева Татьяна Алексеевна; Ленинградский государственный университет им. А.С. Пушкина. Санкт-Петербург, 2014. - 176 с.

8. Пометун О. I. Компетентнісний підхід найважливіший орієнтир розвитку сучасної освіти / О. І. Пометун // Рідна школа. - 2005. - № 1. - С. 65-69.

9. Програма дій «Порядок денний на XXI століття: Ухвалена конференцією ООН 3 навколишнього середовища і розвитку в Ріо-деЖанейро (Саміт «Планета Земля», 1992 р.) : Пер. 3 англ. - 2-ге вид. - К. : Інтелсфера, 2000. - 360 с.

10.Равен Дж. Педагогическое тестирование : проблемы, заблуждения, перспективы : пер. с англ. / Дж. Равен. - М. : Когито-Центр, 1999. - 144 с.

11.Радкевич В.О. Професійна освіта і навчання для сталого розвитку суспільства Професійно-технічна освіта. - 2015. - № 4 (69). - С. 7-11.

12.Розанов Л. Геоэкология: учебнометодическое пособие для вузов / Л. Розанов. - М. : Дрофа, 2010. - 272 c.

13.Humen Ecology, Humen Economy: Ideas for an Ecollogically Sustainable Future / Edited by M. Diesendorf and C. Hamilton. - St Leonard, Australia : Allen \& Unwin, 1997. $-378 \mathrm{p}$.

14. Tuning Educational Structures in Europe. EC: Educational and Culture. Socrates-Tempus, 2006. [Електронний ресурс]. - Режим доступу: http://www.eua.be/eua/en/projects_ects.jspx.

\section{Реферат}
Формирования геоэкологической компетентности будущих специалистов по туристическому обслуживанию в контексте устойчивого развития

\author{
Сенькив Марьян, \\ аспирант Института профессионально-технического образования
} НАПН Украинь

КЛЮЧЕВЫЕ
СЛОВА:
образование
устойчивого
развития,
профессиональное
образование,
компетентностный
подход,
геоэкологическая
компетентность

В статье раскрыто исследования отечественными и зарубежными учеными проблемы обеспечения качества профессионального образования в условиях устойчивого развития украинского общества, нормативно-правовые документы по модернизации профессионального образования в Украине. Отмечена необходимость постоянного обновления содержания профессионального обучения с учетом потребностей общества, требований национального рынка труда. Акцентировано внимание на важности формирования социальных и творческих черт личности специалиста, его профессионально важных качеств. Рассмотрены условия формирования геоэкологической компетентности будущих специалистов по туристическому обслуживанию в контексте устойчивого развития; приведены определения понятий: «компетентность», «устойчивое развитие», «геоэкологическая культура»; обоснованна сущность компетнтнисного подхода к формированию системы знаний, умений и навыков будущих специалистов по туристическому обслуживанию, что соответствует требованиям сферы туризма; сформулировано 
Розділ II. Методичні засади професійного навчання майбутніх фахівців

авторское понятие «геоэкологическая компетентность будущих специалистов по туристическому обслуживанию»; раскрыты компоненты геоэкологической компетентности (ценностно-мотивационный, инновационно-когнитивный, субъектно-деятельностный, рефлексивно-оценочный).

Изучено «Национальную стратегию развития образования в Украине на период до 2021 года», которая среди перспективных задач определяет обновление целей и содержания образования на основе компетентностного подхода и личностной ориентации, учета мирового опыта и принципов устойчивого развития. Охарактеризован процесс формирования геоэкологической компетентности специалистов по туристическому обслуживанию (на примере дисциплины «Экология») и выделены главные задачи по формированию геоэкологической компетентности будущих специалистов по туристическому обслуживанию, согласно которым происходит становление личности в социальном и профессиональном средах. Внимание уделено основным положениям реализации политики совершенствования системы профессионального образования в контексте устойчивого развития. Определено, что реализация указанных задач устойчивого развития будет невозможна без приобретения специалистами ключевых компетентностей (инструментальных, межличностных и системных), то есть профессиональной компетентности, в структуре которой особое место принадлежит геоэкологической компетентности.

\section{Abstract \\ Geo-ecological competence formation for future tourism services specialists in the sustainable development movement}

Senkiv Marian, postgraduate student at the Institute of Vocational Education and Training of NAES of Ukraine

KEY WORDS:
sustainable
development creating,
VET,
competence-based
approach,
geo-ecological
competence

The article is devoted to national and foreign scientists researches on the problem of VET quality assurance specialists in the sustainable development movement of Ukrainian society, legislation on VET content in Ukraine. The necessity for permanent upgrading VET content considering society needs and national LM requirements. The importance of forming a person's social and creative features and his/her professionally important qualities is emphasised. Terms and conditions for future tourism services specialists' geo-ecological competence forming in the sustainable development movement are described; the definition of concepts "competence", "sustainable development", "geo-ecological culture" is given; the essence of competence-based approach for designing the knowledge, skills and qualities system for future tourist services specialists according to tourism sector requirements; the author's concept "geo-ecological competence of future tourism services specialists" is phrased; the geo-ecological competence components (value-motivational, innovationcognitive, subject-activity, reflexive-evaluative) are revealed.

The National Strategy for Education Development 2021 was studied and outlined its prospective tasks to update education goals and contents in accordance with competencebased approach and personal positioning taking into account world experience and principles of sustainable development. The process of future tourism services specialists' geo-ecological competence forming (on the example of the subject "Ecology") is characterized and main tasks for future tourism services specialists' geo-ecological competence forming supporting personal becoming in social and professional environments are outlined. The emphasis is placed on policy implementation for VET system improve in the sustainable development movement. It is determined that realization of sustainable development specified tasks will be impossible without obtaining key competencies by specialists (instrumental, interpersonal and systemic) in other words, professional competence with special place for geo-ecological competence.

\section{References}

1. Ukaz Prezydenta Ukrainy vid stratehiiu rozvytku osvity v Ukraini na period do 25.06.2013 r. № 344/2013 «Pro Natsionalnu 2021 roku». - [Elektronnyi resurs]. - Rezhym 
dostupu:

http://zakon5.rada.gov.ua/laws/show/344/2013

2. Anufriieva O. L. Kompetentnisnyi pidkhid do ekonomichnoi osvity / O. L. Anufriieva. - [Elektronnyi resurs]. Rezhym dostupu : www.cippe.edu.ua

3. Bondar O. I. Ekolohichna osvita dlia staloho rozvytku u zapytanniakh ta vidpovidiakh : naukovo-metodychnyi posibnyk dlia vchyteliv / Bondar O. I., Baranovska V. Ye., Yeresko O. V. ta in.; za red. O. I. Bondaria. - Kherson : Hrin D. S., 2015. - 228 s.

4. Demydova N. N. Teoryia y metodyka formyrovanyia heoekolohycheskoi kultury shkolnykov sredstvamy heohrafy: dyssertatsyia doktora pedahohycheskykh nauk: 13.00 .02 /Demydova Natalia Nykolaevna; [FHBOU VPO «Nyzhehorodskyi hosudarstvennыi pedahohycheskyi unyversytet»]. - Nyzhnyi Novhorod, 2012. - 346 s.

5. Ievropeiska ekonomichna komisiia (IeEK) OON «Osvita v interesakh staloho rozvytku v Ukraini» vid 2005r. - [Elektronnyi resurs]. - Rezhym dostupu: http://dea.gov.ua/chapter/koncepciya_regional4n oi sistemi osviti dlya stalogo rozvitku

6. Kompetentnisnyi pidkhid u suchasnii osviti: svitovyi dosvid ta ukrainski perspektyvy: Biblioteka z osvitnoi polityky: kolektyvna monohrafiia / [N.M. Bibik, L.S. Vashchenko, O.I. Lokshyna [ta in.]; za zah. red. O.V. Ovcharuk. - K. : «K.I.S.», 2004. - 112 s.

7. Nechaeva T. A. Formyrovanye heoэkolohycheskoi kompetentnosty pry podhotovke spetsyalystov po turyzmu $\mathrm{V}$ obrazovatelnыkh uchrezhdenyiakh sredneho professyonalnoho obrazovanyia: dyssertatsyia kand. ped. nauk: 13.00.08 / Nechaeva Tatiana Alekseevna; Lenynhradskyi hosudarstvennyi unyversytet ym.A.S. Pushkyna. - SPb , 2014. $176 \mathrm{~s}$.

8. Pometun O. I. Kompetentnisnyi pidkhid - naivazhlyvishyi oriientyr rozvytku suchasnoi osvity / O. I. Pometun // Ridna shkola. - 2005. № 1. - S. 65-69.

9. Prohrama dii «Poriadok dennyi na XXI stolittia»: Ukhvalena konferentsiieiu OON z navkolyshnoho seredovyshcha i rozvytku v RiodeZhaneiro (Samit «Planeta Zemlia», 1992 r.): Per. z anhl. - 2-he vyd. - K. : Intelsfera, 2000. $360 \mathrm{~s}$.

10.Raven Dzh. Pedahohycheskoe testyrovanye : problemb, zabluzhdenyia, perspektyvy : per. s anhl. / Dzh. Raven. - M. : Kohyto-Tsentr, 1999. - 144 s.

11.Radkevych V.O. Profesiina osvita i navchannia dlia staloho rozvytku suspilstva Profesiino-tekhnichna osvita. - 2015. - № 4(69). - S. 7-11.

12.Rozanov L. Heoekolohyia: uchebnometodycheskoe posobye dlia vuzov. - M. : Drofa, 2010. - $272 \mathrm{~s}$.

13.Humen Ecology, Humen Economy: Ideas for an Ecollogically Sustainable Future / Edited by M. Diesendorf and C. Hamilton. - St. Leonard, Australia : Allen \& Unwin, 1997. $378 \mathrm{p}$.

14.Tuning Educational Structures in Europe. EC: Educational and Culture. Socrates-Tempus, 2006. - [Elektronnyi resurs]. - Rezhym dostupu: http://www.eua.be/eua/en/projects ects.jspx 